\title{
AN ANALYSIS OF THE RELATIONSHIP BETWEEN THE QUALITY OF CORPORATE GOVERNMENT ACTIVITIES AND THE FINANCIAL PERFORMANCE BY PANEL DATA ANALYSIS UNDER CROSS- SECTIONAL DEPENDENCY: AN INVESTIGATION ON THE COMPANIES LISTED IN THE BORSA ISTANBUL CORPORATE GOVERNANCE INDEX
}

\author{
Mustafa ÖZYEŞIL ${ }^{1}$, Havane TEMBELO ${ }^{2}$
}

\begin{abstract}
In this study, the effects of corporate governance ratings on financial performance are investigated. For this purpose, a sample that include the annual data of the 27 listed companies in the Borsa Istanbul's Corporate Governance Index for the 2012-2018 a period are used. The existence of cross-sectional dependence among the firms included in the sample is analyzed by Breusch and Pagan (1980) LM test, Pesaran (2004) LM test, Pesaran (2004) CD test and Baltagi, Feng and Kao (2012) LMBC test. According to test results, the cross-sectional dependence between firms is determined. Stationarity level of the series is examined by CADF panel unit root test developed by Pesaran (2007). According to the findings of the test, all series are determined as stationary. The causality relationship between the series are examined by Dumitrescu and Hurlin (2012) method and the causality relations are found from the corporate governance rating of the firms to the operating profits. The coefficients in the econometric model are estimated using Westerlund (2007) OLSAdj method and it is determined that the annual operating profits will increase by 110.74 Million TL when corporate governance quality (ratings) of the firms increase by 1 unit.
\end{abstract}

Keywords: Corporate Governance, Corporate Governance Ratings, Panel Data Analysis, Panel Unit Root Test, Panel Causality Test.

JEL Classification: G34, C23, C31, C51

FIRMALARIN KURUMSAL YÖNETIM UYGULAMALARI İLE FINNANSAL PERFORMANSI ARASINDAKİ İLISSKININ YATAY KESITT BAĞIMLILIĞI ALTINDA PANEL VERI YÖNTEMİ İLE ANALIZİ: BORSA İSTANBUL KURUMSAL YÖNETIM ENDEKSINDE YER ALAN FİRMALAR ÜZERINE BİR İNCELEME

$\ddot{O} z$

$\mathrm{Bu}$ çalışmada, firmaların kurumsal yönetim derecelendirme notlarının finansal performans üzerindeki etkileri araştırılmıştır. Bu amaçla Borsa İstanbul'un 2012-2018 dönemi Kurumsal Yönetim Endeksinde yer alan 27 borsa şirketinin yıllık verilerini içeren bir örneklem kullanılmıştır. Örneklemde yer alan firmalar arasında yatay kesit bağımlılığın varlığı Breusch ve Pagan (1980) LM testi, Pesaran (2004) LM testi, Pesaran (2004) CD testi ve Baltagi, Feng ve Kao (2012) LMBC testi ile analiz edilmiştir. Test sonuçlarına göre, firmalar arasında yatay kesit bağımlılığı belirlenmiştir. Serinin durağanlık seviyesi Pesaran (2007) tarafindan geliştirilen CADF panel birim kök testi ile incelenmiştir. Testin bulgularına göre tüm seriler durağan olarak belirlenmiştir. Seriler arasındaki nedensellik ilişkisi Dumitrescu ve Hurlin (2012) yöntemi ile incelenmekte ve firmaların kurumsal yönetim derecelendirmelerinden faaliyet kârlarına doğru nedensellik tespit edilmiştir. Ekonometrik modeldeki katsayılar Westerlund (2007) OLSAdj yöntemi kullanılarak tahmin edilmiştir ve firmaların kurumsal yönetim kalitesi (derecelendirme) 1 birim arttığında yıllık faaliyet karının 110,74 Milyon TL artacağı belirlenmiştir.

1 Dr. Öğr.Üyesi, İstanbul Aydın Üniversitesi, Anadolu Bil Meslek Yüksekokulu. İşletme Yönetimi (İngilizce), mozyesil@aydin.edu.tr ORCID: 0000-0002-4442-7087

${ }^{2}$ Uzman, T.C. Sağlık Bakanlığı, İstanbul İl Sağlık Müdürlüğü, havane.tembelo@ saglik.gov.tr, ORCID: 0000-0003-3394-4166 
Anahtar Kelimeler: Kurumsal Yönetim, Kurumsal Yönetim Derecelendirme Notu, Panel Data Analizi, Panel Birim Kök Testi, Panel Nedensellik Testi

JEL Kodları: G34, C23, C31, C51

\section{Introduction}

The concept of corporate governance is one of the most popular topics in today's finance world. What makes corporate governance so important is financial failure of the companies because of the unethical transactions and corruption scandals. Because, in all company cases, particularly in Enron, Xerox and Worldcom crises, managerial ability was too low and / or the top management tended to behave in favor of only certain groups instead of all stakeholders.

Corporate governance is based on the professional management of the companies and refers to working for the interests of all related stakeholders. Therefore, according to finance literature, the concept of corporate governance is regarded as a strategic process that may enables companies to be sustainable.

In this study, the relationship between corporate governance activities applied by the firms and their operational profitability are examined. 27 firms listed in Borsa İstanbul Corporate Governance Index are included in the sample. To conduct statistical analysis, the annual corporate governance ratings and operating profitability margins of the 27 firms for the period of 2012-2018 are obtained.

Since there is the sections (firms) included in the sample, the new generation of panel data analysis method is performed in the study. Firstly, the stationariness of the series is measured by Pesaran (2007) CADF unit root test and then the causality relationship between the series is examined by Dumitrescu and Hurlin (2012) method and finally the coefficients in the econometric model are estimated by using WestLund (2007) OLSAdj method and the findings are interpreted.

\section{Importance of Research and Contribution to Literature}

The main objective of this study is to contribute to existing literature. This study will try to confirm the results of previous studies in the literature by providing up-to-date findings on the relationship between corporate governance and financial performance. This study is also important in terms of testing the success of the ratings given by rating agencies in guiding investors.

The majority of the studies in the literature used ROA and ROE as the main indicators for measuring financial performance. However, ROA and ROE indicators are calculated based on the Net Profit / Loss item, which does not represent the net contribution from the main activities of the firm. In this study, it is tried to find out the relationship between corporate governance practices and its benefits created for any firms, that's why Net Operating Income and Loss item which doesn't include other operating income and loss is used.

\section{Limitations of Research}

In the study, only those firms which are included BIST - Corporate Governance Index and received corporate governance ratings are analyzed. 
The net impact of corporate governance practices on firms' financial performance will be better analyzed with the inclusion of non-corporate governance firms.

In the study, the companies are determined as involving with corporate governance practices according to whether they have a rating. Firms with ratings are regarded as followers of corporate governance practices while others are considered as non-dealing with these practices. In order to get sufficient evidence to define companies as involving with corporate governance practices except for the rating note, no other observations or surveys have been conducted. Therefore, it may be possible that sample may include firms that are not dealing with corporate governance practices indeed.

\section{Proposed Further Researches}

The further analyzes are recommended for the academicians who carry out research on this field as follow:

- First of all, the sample should be designed in two groups as companies performing and not performing corporate governance practices. In this way, it will be examined whether there is a statistically significant difference between the two groups in terms of financial performance and thus the impact of corporate governance practices on the firm's financial performance can be seen more clearly.

- Adjusted ROA and ROE indicators as financial performance indicators in the analysis would be more appropriate in terms of reflecting the actual operating performance of the firms. In adjusted ROA and ROE calculations, Net Income \& Loss items should be replaced by Net Operating Income \& Loss item.

- Not only the ratings received but also other techniques such as conducting observation, survey and interview should be used to determine whether the companies are fulfilling their corporate governance practices and thus the rating scores should be confirmed more clearly.

In section 2, the concept of corporate governance is being examined and corporate governance practices in the World and Turkey is also discussed in detail. In the third section, under the literature review, previous studies conducted in the field of corporate governance are examined. Section 4 provides information about the data used in the analysis and the structure of the sample. Section 5, the test and the methods used in the analysis are explained together with the reasons. In section 6 , the test results and the findings are explained, and in the last section, test results are interpreted and general evaluation and recommendations are made.

\section{Corporate Governance Concept}

Corporate governance can be simply described as good management of the firms. Here the term good refers to both quantitative and qualitative elements that will enable the company to achieve the strategic objectives defined in the vision statement. It requires sum of the management and supervision rules for international business enterprises (Glinkowska and Kaczmarek, 2015:85). In order to make sure investors that firm management will be loyal to determined objectives, firms need to establish efficient supervision system in the workplace. Although there is no consensus on the definition of corporate governance, the definition of the OECD can be regarded as basis. 
According to the OECD, corporate governance is the process that covers a series of relationships between the board of directors, shareholders and other stakeholders and sets out a structure where the company's objectives are determined and shows how to achieve these go als and how to control the performance (OECD, 2015:13). The OECD has also made the definition of good corporate governance. According to the $\mathrm{OECD}$, good corporate governance is defined as a process that directs the company's top management in line with the interests of its stakeholders and facilitates effective audit (Yeğen, 2016: 5).

The concept of corporate governance has many components. Each sub-component interacts with one another and contributes positively to the institutionalization process of firms. The common objective of all components is to achieve that companies are managed and professionally by ensuring the separation of management and ownership concepts from each other. As the components of corporate governance, the following concepts underlined in the current literature are; Number of Independent Directors, Board Leadership Structure, Board Size, Audit Committee, Board Attributes, Board Meeting (Yusoff and Alhaji).

It is possible to show the board structure as the most important component of the corporate governance concept and the board structure includes the board size and board leadership subcomponents and has a significant impact on the performance of the company (Rostami et.al, 2016:138)

Corporate governance concept is trying to enhance the role of independent directors who are expected to work not only in favor of firm management but also for all stakeholders of the company (Mcchahery and Vermeulen, 2014:3)

The audit committee should provide control of the internal audit function in the firms and audit the relationship of the internal audit department with external auditors (OECD, 2015:43)

\subsection{Corporate Governance Practices in the World}

The OECD is the first institution that published corporate governance principles. The corporate governance principles published by the OECD are still used as basic principles today. Principles are classified under 6 main sections as follows: "Ensuring the basis of effective corporate governance framework", "Shareholders' rights and fundamental partnership functions", "Fair treatment of the shareholders", "Role of stakeholders", "Responsibilities related to public disclosure and transparency", " The responsibilities of the board"(OECD, 2015:13).

Many researchers and organizations carry out studies other than OECD on the concept, scope, and principles of corporate governance. The most important of these studies is the research published by Gompers, Ishii and Metrick in 2003. In their study, they developed the GIM index, which measures the relationship between corporate governance performance and firm value. This index is based on 24 corporate governance rules set by the Investor Responsibility Research Center (IRRC). The index gives equal weight to each IRRC rule, and during the 1990s, there is a negative relationship between the firm value measured by the Tobin $Q$ indicator and the index value. To find out relationship between firm value and corporate governance, they conducted an analysis that covers 1500 large firms during the period 1990 - 1998. They calculated the index score of each firm and they have developed an investment strategy such as buying stocks when the index points of the firms are lowest and selling them when the index reaches highest points. 
As a result of the analysis, they found that such an investment would yield $8.5 \%$ abnormal return to the investor. According to findings, they found a positive relationship between shareholder rights and firm value and financial performance.

Bebchuk et al (2008) make another study in the field of corporate governance. They argued that 24 provisions of IRRC, which is the basis of the GIM index should be examined according to their relationship with the firm value, and from this point of view, it would be revealed that not all provisions have the same importance level. They selected 6 of the 24 rules of the IRRC as the most important according to their relationship with the firm value and formed an index under the name E index over these rules. The rules covered by the index E are as follows; Staggered board, Limitation on amending bylaws, Limitation on amending the charter, Supermajority to approve a merger, Golden parachute, and Poison pill. They created another index under the name $\mathrm{O}$ on the remaining 18 rules of the IRRC. They found that during the $1990-2003$ analysis period, the $\mathrm{E}$ index was more successful than the $\mathrm{O}$ index in explaining the changes in firm value and return on equity.

Brown and Caylor (2006) conducted another study on corporate governance and firm performance. They argued that both GIM index developed by Gompers et al. (2003) and E index developed by Bebchuk et al. (2005) focus on only external factors of corporate governance, and ignore internal factors. They emphasized that both indices consist of IRRC provisions, which are prepared against the takeover of the management. Therefore, they developed an index called Gov-Score based on 51 company-specific provisions that included both internal and external factors. The index is based on the data of 1868 companies in 2003. Each of the 51 rules for each firm is coded as 0 and 1, depending on whether or not the Institutional Shareholder Services (ISP) has confirmed whether the firms have applied the provisions adequately. They found that the sub-index, which was formed from the 7 rules that were most related to the firm value, out of the 51 rules they created, explained the relationship between corporate governance and firm performance much better. They found that the sub-index, which was formed from the 7 rules that were most related to the firm value, out of the 51 rules they created, explained the relationship between corporate governance and firm performance much better. They could not find any significant relationship between the five rules related to accounting and public policies and firm performance.

Prommin et al. (2014) examined the effects of corporate governance on stock liquidity for the Thailand case through a model based on agency theory. The main purpose of this study is to show whether the demand for stocks of firms developing effective corporate governance tools is higher than the stocks of other firms. For this purpose, they worked on a sample that includes 100 large-scale companies during the period of 2006-2009 in Thailand. According to the results of the analysis, they found that as the quality of corporate governance practices increased, the liquidity of stocks improved significantly. According to the results of the test, a 1 unit increase in the standard deviation of corporate governance quality increases the liquidity of stocks by $26.19 \%$.

\subsection{Corporate Governance Practices in the Turkey}

Capital Markets Board (CMB) has authority and responsibility in establishment of the conceptual framework of corporate governance principles in Turkey and in ensuring the necessary control mechanisms on implementation. Corporate governance principles were first published by the CMB in 2003. The principles are based on the OECD report published in 1999. 
The principles are mainly prepared by taking into consideration the publicly held companies (listed firms) and conducted under the principle (OECD, 2015:13). Therefore, listed firms should include a part under the name of "compliance with corporate governance principles" in their annual activity reports and in this part, they should provide sufficient information about progress of corporate governance activities to the public. The legal regulation regarding corporate governance principles is the Communiqué on the Determination and Implementation of Corporate Governance Principles, Series: IV, No: 54, published by the CMB. According to the current regulation, corporate governance principles consist of four main topics in line with OECD: shareholders, public disclosure and transparency, stakeholders and board of directors. In order to determine the quality of corporate governance practices and to document their performance in compliance with corporate governance principles, companies can obtain rating score about corporate governance principles. The rating service can be obtained from the rating companies authorized by the CMB to perform this activity exclusively. In 2007, CMB issued Communiqué on Principles Regarding Rating Activities and Rating Agencies in the Capital Market, Series: VIII, No: 51, in order to ensure that companies receive corporate governance rating services in a reliable and effectively.

Corporate Governance Association of Turkey established to ensure widespread adoption of corporate governance practices and to understand the importance of corporate governance and the creation of the awareness on this issue, has been operating since 2003 .

Corporate Governance Index (XKURY) has been established within Borsa Istanbul in order to monitor the performances of the companies that have implemented these practices related to corporate governance principles. The index is based on a list of companies whose shares are traded on the Borsa İstanbul markets (except for the Watch list Market, $\mathrm{C}$ group and D group lists) has been calculated since 31.08.2007. Firm's rating should be at least 7 rating out of 10 in compliance with the corporate governance principles and also get at least 6,5 out of 10 in each main sections of the corporate governance principles.

According to the data of Borsa İstanbul, there are currently 47 companies traded in the index. The companies included in the index are shown in the table in Appendix 1.

The annual price and transaction volume information since the first opening date of the index can be shown as follows:

Chart 1: Corporate Governance Index Price and Volume By Years

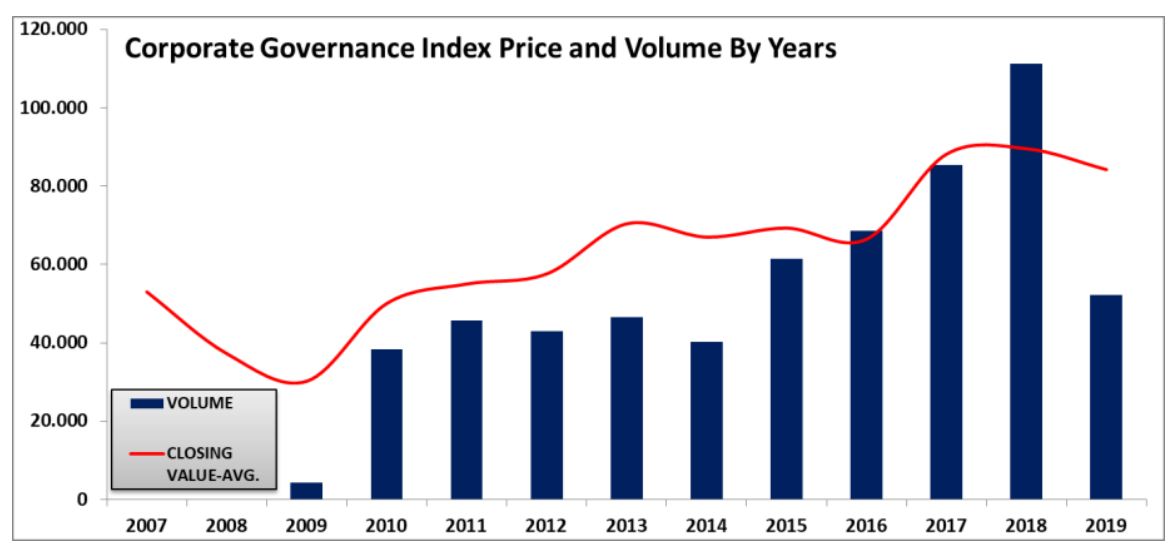


Turkish Industry \& Business Association (TUSIAD) is one of the organizations to apply corporate-level study on corporate governance in Turkey. TÜSİAD has prepared a report, which is a guide for companies and focuses on the formation, independence and agendas of the boards of directors, which have the greatest responsibility for the establishment and implementation of corporate governance.

Corporate Governance Association of Turkey (TKYD) that was established in 2003 with the mission of recognition and development of corporate governance practices in Turkey, is a voluntary non-governmental organization. The Association regularly conducts corporate governance perception surveys in each city across the country and publishes the results of the research as a report. In order to improve the quality of corporate governance practices in companies, it regularly organizes individual and corporate trainings. It publishes a quarterly corporate governance journal including the latest developments and legal regulations related to corporate governance.

\section{Literature Review}

Kara et.al (2015), investigated the effect of corporate governance practices on firm's financial performance. They conducted panel data analysis based on sample consist of firms listed corporate governance index during the 2006-2012. They used Tobin's q value and leverage ratio as financial performance metrics. According to the results of the analysis, they found out that there is a statistically significant positive relationship between financial performance and corporate governance scores. Based on their findings, there is meaningful relationship between ROE, ROA and corporate governance scores.

Cengiz (2016), performed an analysis to find out whether firms are listed in the XKURY index differ from other listed firms included the Bist-100 index in terms of financial performance. In other words, the author tried to find a meaningful relationship between firm performance and corporate governance rating scores. ROE, ROA and net profit margin ratios are used in the study as financial performance indicators. Based on findings, it shows that firms included in the XKURY index have higher financial ratios. Moreover, based on the comparison between firms included in XKURY each other, it can be concluded that firms with higher ratings have better financial performance.

Ciftci et. al. (2019) studied the relationship between internal corporate governance and firm performance based on sample includes family companies. The analyzed relationship between ownership concentration and firm performance. They considered ROA and Tobin's q value as the dependent variables and financial performance indicators. In family-based companies, they observed a more concentrated ownership structure and found out that a more concentrated ownership structure ensures firms perform better.

Yeğen (2016), examined effect of the corporate governance ratings on the firm performance. He established a sample that includes 31 companies listed in the Corporate Governance Index in Borsa İstanbul and have corporate governance ratings at least for 3 terms between 2011 and 2015. In the study, it was determined that Tobin $q$ value has a positive and statistically significant relationship with the corporate governance ratings but no significant relationship was found with the asset return rate (ROA) and the return on equity (ROE). 
Boyacıoglu (2017), studied the relationship between corporate governance practices and financial performance of the firms.

He designed a sample that consist of 22 manufacturing firms are listed in the corporate governance index and hold corporate governance ratings for the period between 2010 and 2016. Tobin's Q ratio was used to represent firm value and other financial metrics such as, tangible assets turnover, return on equity, return on assets were used to represent financial performance of the firm. Based on these variables, TOPSIS multivariate decision making method was applied and financial performance scores and corporate governance rating scores were compared.

Balkan (2018), analyzed the effect of the transition to corporate governance on firm performance by using the pre- and post-index data of firms included in the Borsa İstanbul Corporate Governance Index. Financial multipliers such as profit margins, asset and return on equity, were used for indicating firm performance.

\section{Data Set and Model}

In the study, the first version of the sample included 47 companies that have corporate governance ratings. However, since some companies' ratings do not cover all years of the 20122018 analysis period, these firms were excluded from the sample. Firms whose rating scores cover the analysis period are included in the sample and thus in the final version of the sample 27 firms are included in the analysis. The list of the companies included in the analysis and their ratings are shown by years in table Appendix 2.

To determine effects of the corporate governance practices on the firm's financial performance, we built a sample based on 27 listed firms are included in Corporate Governance Index. In the analysis, the annual data of the corporate governance ratings and financial performance indicators are used. As a financial performance indicator, Operating Profit, which are created based on firm's basic operations, is used. Operating Profit item is obtained from income statement published in www.kap.org.tr and corporate governance rating information is obtained from www.tkyd.org. Basic descriptive statistics of the sample and correlation matrix of the variables are provided in table Appendix 3.

The econometric model created in the study is as follows:

$$
\text { Operating Profit\&Loss } i t=\alpha_{0}+\alpha_{1} \text { Rating }_{i t}+\epsilon_{i t}
$$

\section{The notations in the equation are as follows:}

The Rating indicates the corporate governance rating of the firms [0-100], the Profit refers to operating profit / loss of companies (Million TL), I represents firms included in the sample, $\alpha_{1}$ refers to coefficient of independent variable (in this study rating) and $\epsilon_{i t}$ shows error terms of the series, which is free of econometric problems ${ }^{3}$.

Since the companies with high corporate governance rating scores are expected to have a higher operating profitability, $\alpha_{1}$ is expected to be positive $\left[\alpha_{1}>0\right]$.

\footnotetext{
${ }^{3}$ In this study, it was tried to prevent the problem of heteroscedasticity by taking the logarithms of the series but this was not possible since there were also sections which recorded loss by period and firm in the sample. Therefore, it was tried to convergence series to each other as a numerical size by converting the annual profit / loss data to TL million (currency).
} 


\section{Method}

We consider dependence may exist between sections (here firms) included in the sample because of reasons such as similarity, interaction etc.

Therefore, firstly the existence of cross-sectional dependence between the firms included in the analysis is tested. Breusch and Pagan LM tests (Breusch and Pagan, 1980: 245), Pesaran LM test (Pesaran, 2004:435), Pesaran CD test (Pesaran, 2004:435) and Baltagi, Feng and Kao LMBC tests (Baltagi, Feng, Kao, 2012:170) will be used for the cross-sectional dependency.

Stationary series, which doesn't show extraordinary fluctuation or doesn't include outlier values is so crucial in terms of increasing predictive power of the established model. Stationary series are series that do not contain extreme and excessive volatile values and their variance and covariance values are close to the expected value, in other words, they tend to show normal distribution features. As a result, the findings of the regression model based on these series will be reliable.

Stationarity levels of the series are investigated by CADF panel unit root test which was developed by Pesaran (Pesaran, 2007:285), since it is considering the existence of the cross sectional dependence in the series.

Similarly, the coefficients in the models are estimated by the Bias Adjusted OLS (OLSAdj) method developed by Westerlund (Westerlund, 2007: 502) because it is taking into account the cross-sectional dependence between the series.

In order to determine the direction of interaction between the series, panel causality test is applied through the Dumitrescu and Hurlin (2012:1455) panel causality test.

\section{Findings and Results}

\subsection{Horizontal Cross-Section Dependence Test}

Nowadays, because of globalization, the interaction between economic activities has been intensively increasing. As a natural consequence of this process, convergence between firms has been emerged therefore the possibility and speed of effects of any cases observed in one firm to another has increased remarkably compared to past years. Especially for companies within the same country, this interaction is observed in a much more depressive way. According to econometric literature, this situation is defined as horizontal section dependence. New Generation (Second Generation) Panel Data Analysis methods perform analysis by taking into consideration the possible dependence between the sections (countries, firms, etc.) that constitute the panel.

First, when such a dependency is detected between horizontal sections forming the panel, it is necessary to use New Generation Panel Data Analysis methods, which take into consideration the horizontal dependency.

Horizontal cross-sectional dependence tests were initiated with Breusch and Pagan LM test (Breusch and Pagan, 1980: 245), based on a standard panel data model as follows:

$$
y_{i t}=\beta_{i}^{\prime} x_{i t}+u_{i t}, \quad i=1, \ldots, N ; t=1, \ldots, T
$$


Here $x_{i t}$; represents the matrix of extrinsic variables in the size of $k x 1$, and $u_{i t}$; shows a series of econometically smooth error terms.

Berusch and Pagan (Breusch and Pagan, 1980: 245), based on the Lagrange Multiplier: LM test statistic to test the existence of a dependence between the horizontal sections:

$$
L M=T \sum_{i=1}^{N-1} \sum_{j=i+1}^{N} \hat{\rho}_{i j}^{2}
$$

Pesaran (Pesaran, 2004:435), in cases where the number of horizontal cross-sections is very high, scaled Berusch and Pagan (Breusch and Pagan, 1980: 245) the LM test and expanded Equation (3) as follows:

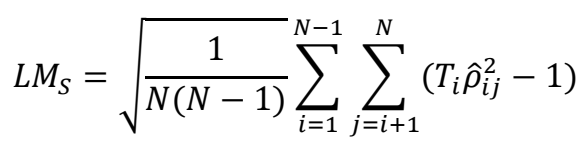

Pesaran (Pesaran, 2004:435), developed the CD test statistic by solving the probable size distortion problem in $L M$ and $L M_{S}$ tests:

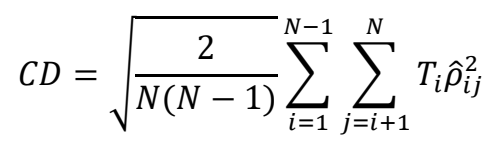

Baltagi, Feng and Kao (Baltagi, Feng, Kao, 2012:170), created the $L M_{B C}$ test (Bias-Corrected LM) statistic by correcting the asymptotic deviations in the LM test:

$$
L M_{B C}=\sqrt{\frac{1}{N(N-1)} \sum_{i=1}^{N-1} \sum_{j=i+1}^{N}\left(T_{i} \hat{\rho}_{i j}^{2}-1\right)-\frac{1}{2(T-1)}}
$$

\section{The hypotheses of these tests:}

$H_{0}: \operatorname{Cov}\left(\varepsilon_{i t}, \varepsilon_{j t}\right)=0$ There is no cross-sectional dependence in the panel. $H_{1}: \operatorname{Cov}\left(\varepsilon_{i t}, \varepsilon_{j t}\right) \neq 0$ There is a cross-sectional dependence in the panel.

In this study, cross-sectional dependence tests are performed by using E-views 10 program and the findings are presented in Table 1.

Table 1: Cross-Sectional Dependency Test Results

\begin{tabular}{|c|c|c|c|c|}
\hline & $\boldsymbol{L M}$ & $\boldsymbol{L M}$ & $\boldsymbol{C D}$ & $\boldsymbol{L M}_{\boldsymbol{B C}}$ \\
\hline Rating & $1668.28 * * *(0.00)$ & $49.71 * * *(0.00)$ & $\begin{array}{c}40.05 * * * \\
(0.00)\end{array}$ & $47.46 * * *(0.00)$ \\
\hline Operating Profit\&Loss & $1101.98 * * *(0.00)$ & $28.34 * * *(0.00)$ & $16.13 * * *(0.00)$ & $26.09 * * *(0.00)$ \\
\hline
\end{tabular}

Note: Numbers in parentheses indicate probability values. $* * * *$, shows the existence of cross-sectional dependence between firms in the related series at the $1 \%$ significance level. $L M_{B C}$ test statistics cannot be calculated for the models.

According to the findings in Table 1, there is a cross-sectional dependence among the firms included in this study. In other words, a significant economic shock in one of these companies has a significant impact on others. Therefore, it is decided to use new generation panel analysis method that considers this situation. 


\subsection{Panel Unit Root Test}

Stationarity degree of the series used in the analysis were examined by Pesaran (Pesaran, 2007:285).

CADF panel unit root test, which considers the cross-sectional dependence among the firms. In this method, the test statistic required for the unit root test, which will be performed on a y series, can be shown as follows:

$$
\Delta Y_{i t}=\alpha_{i}+\beta_{i} Y_{i t-1}+\lambda_{i} f_{t}+\varepsilon_{i t}
$$

Here $f_{t}$, shows common factors affecting the series.

In the CADF test, firstly, the unit root parameters $\left(\rho_{i}\right)$ are calculated for each firm and then the unit root test statistic (CIPS) that is valid for the overall panel is reached.

$$
\text { CIPS }=\frac{1}{N} \sum_{i=1}^{N} \rho_{i}
$$

The hypotheses of the CADF panel unit root test are as follows:

$H_{0}: \beta_{i}=0$, The series is not stationary for all firms.

$\mathrm{H}_{1}:\left\{\begin{array}{cl}\beta_{\mathrm{i}}<0, \mathrm{i}=1,2, \ldots, \mathrm{N}_{1} . & \text { The series are stationary for the some of firms. } \\ \beta_{\mathrm{i}}=0, \mathrm{i}=\mathrm{N}_{1}+1, \mathrm{~N}_{1}+2, \ldots, \mathrm{N} . & \text { The series are not stationary for the some of firms. }\end{array}\right.$

In the study, Pesaran (Pesaran, 2007:285) CADF panel unit root test is done by using Gauss 10 program and codes written for this program and the results obtained are presented in Table 2.

Table 2: CADF Panel Unit Root Test Results

\begin{tabular}{|c|c|c|c|c|}
\hline \multirow{2}{*}{ Variables } & \multirow{2}{*}{ CIPS Test Statistics } & \multicolumn{3}{|c|}{ Critical Value } \\
\cline { 3 - 5 } & & $\mathbf{\% 1}$ & $\mathbf{\% 5}$ & $\mathbf{\% 1 0}$ \\
\hline Rating & -9.60 & -1.85 & -1.61 & -1.49 \\
\hline Operating Profit \& Loss & -4.30 & -1.85 & -1.61 & -1.49 \\
\hline
\end{tabular}

According to the results shown in Table 2, all series are stationary at original values, in other words series are I ( 0 ). Thanks to this finding, a spurious regression problem will not be observed in the analysis performed with the original level values of the series and therefore findings will be reliable. As the series is stationary at the original level values, there is no need to perform panel cointegration test.

\subsection{Panel Regression Analysis}

The coefficients in the models are estimated by using the Bias Adjusted OLS Estimator (OLSAdj) method developed by Westerlund (Westerlund, 2007: 502) by correcting the deviation of the Cup-Fm method of Bai and Kao (Bai and Kao, 2006:26). This method considers the cross-sectional dependence through common factors in the series. It is a robust estimation method for autocorrelation and heteroscedasticity problems. 
In this study, the coefficients in the models are calculated by using Westerlund (Westerlund, 2007: 502) OLSAdj method through Gauss 10 program. The results obtained are presented in Table 3.

Table 3: Panel Regression Analysis Results

\begin{tabular}{|l|c|c|}
\hline & Rating & Constant Item \\
\hline Model 1 & $110.74[703.19]$ & $92.31[201.84]$ \\
\hline
\end{tabular}

Note: Values included in the [ ] are t statistics. The $\mathrm{t}$ statistic table values for the $10 \%, 5 \%$ and $1 \%$ significance levels are respectively; $1.28,1.64$ and 2.32 .

According to the findings in Table 3, there is a positive relationship between corporate governance ratings and firm's financial performance. When the corporate governance rating of companies (quality of corporate governance practices) increases by 1 unit, annual operating profit will react through the same way and increase by 110.74 Million TL. This finding provides useful information about the importance of the quality of corporate governance practices in increasing and sustaining the profitability of firms in the medium and long term. It is understood that the top management of the firms should pay more attention to corporate governance practices. The sign of the coefficient obtained is also consistent with our prior expectations.

\subsection{Panel Causality Test}

In this study, the existence of causality relations between the series is examined by the method developed by Dumitrescu and Hurlin (Dumitrescu and Hurlin, 2012:1455). This method can also consider the cross-sectional dependence between the horizontal cross-sections (firms in this study) and perform causality test accordingly. This test is based on the following models:

$$
\begin{gathered}
y_{i t}=\alpha_{i}+\sum_{k=1}^{K} \gamma_{i}^{(k)} y_{i t-k}+\sum_{k=1}^{K} \beta_{i}^{(k)} x_{i t-k}+\varepsilon_{i, t} \\
x_{i t}=\theta_{i}+\sum_{k=1}^{K} \varphi_{i}^{(k)} x_{i t-k}+\sum_{k=1}^{K} \psi_{i}^{(k)} y_{i t-k}+\epsilon_{i, t}
\end{gathered}
$$

\section{The hypotheses of this test:}

$H_{0}: \beta_{i}=0$, There is no causality from $\mathrm{x}$ to $\mathrm{y}$ in all sections. $H_{1}:\left\{\begin{array}{l}\beta_{i}<0, i=1,2, \ldots, N_{1} . \\ \beta_{i}=0, i=N_{1}+1, N_{1}+2, \ldots, N . \text { There is no causality from } \mathrm{x} \text { to } \mathrm{y} \text { in some sections. }\end{array}\right.$

Dumitrescu and Hurlin (Dumitrescu and Hurlin, 2012:1455) developed two different test statistics to test this hypothesis:

$$
\begin{gathered}
W=\frac{1}{N} \sum_{i=1}^{N} W_{i, T} \\
Z=\sqrt{\frac{N}{2 K}}(W-K)
\end{gathered}
$$


The notations in the equation are as follows:

$W_{i T}$; shows individual Wald statistics.

$K$ represents the expected value of $K W_{i T}$.

In the study, Dumitrescu and Hurlin (Dumitrescu and Hurlin, 2012:1455) panel causality test are performed by using Eviews-10 program and the findings are presented in Table 4.

Table 4: Panel Causality Test Results

\begin{tabular}{|c|c|c|c|}
\hline Null Hypothesis & W Statistics & $\bar{Z}$ Statistics & Probability Value \\
\hline Rating $\rightarrow$ Operating Profit & 2.95 & 1.24 & $0.05^{*}$ \\
\hline Operating Profit $\rightarrow$ Rating & 0.20 & 0.41 & 0.81 \\
\hline
\end{tabular}

Note: $* * *, * *$ and $*$ indicate that there is a causality relationship from the first variable to the second variable at the level of $1 \%, 5 \%$ and $10 \%$ respectively.

According to the findings in Table 4, unidirectional (one-way) causality relationships are determined from the corporate governance quality (Rating) to operating profits (Profit). These results can be regarded in terms of confirming the effects of corporate governance quality on firm's financial performance. These results provide crucial findings for the company management that is trying to sustain their firm's profitability. It can be recommended that managers should firstly improve their corporate governance practice quality.

\section{Conclusion}

In this study, the effects of corporate governance ratings on firm's financial performance is investigated. Analysis is conducted on sample includes 27 public firms that are listed in corporate governance index in Borsa Istanbul. In the analysis, corporate governance ratings are described as explanatory variable while Operating Profit Item is described as dependent variable. Therefore, annual operating profitability and rating scores of the 27 companies for the 2012-2018 period are used.

Econometric model is established and panel analysis method is used. New Generation Panel Data Analysis methods are used because of the expectation of dependency due to convergence between the sections included in the model. The existence of cross-sectional dependence among the firms included in the analysis is examined and it has been determined that there is cross sectional dependency between firms. Therefore, it is decided that the New Generation Panel Data Analysis methods that are considering the cross-sectional dependence should be used.

Stationarity levels of the series used in the analysis are examined by CADF panel unit root test which considers the cross - sectional dependence and it is determined that all series are stationary at original level values. Stationarity of the series at the original level values will ensure the reliability of the coefficients in the regression model. As a result, it is determined that it is not necessary to perform a panel cointegration test since the series is stationary at the original level values.

The coefficients in the models are estimated by using the Bias Adjusted OLS Estimator: OLSAdj method. According to these estimations, when the corporate governance rating of firms increased by 1 unit, annual operating profits would increase by 110.74 Million TL. 
This finding highlights the importance of the quality of corporate governance practices on the profitability of firms. Top management of the firms should regard corporate governance practices as strategic issue in order to reach and sustain target profitability instead of considering them as waste or unnecessary expense.

The existence of causality relations between the series used in the analysis is examined.

According to the findings obtained from this test, the unidirectional causality relationship between the corporate governance quality and financial performance (operating profits) is observed. This result confirms the result obtained in the econometric model created and reveals the effect of corporate governance activities on the profitability of the firms.

As a result, the findings of the study show that the company managers who are trying to sustain operating profitability, should focus on corporate governance efforts as much as possible. They should invest in field more and should approach corporate governance issues as strategic issue to attract both current and potential investors. It can be concluded that managers firstly should try to improve their firm's corporate governance practices.

\section{References}

Bai, J. and Kao, C. (2006). On the Estimation and Inference of a Panel Cointegration Model with Cross-Sectional Dependence. in Badi Baltagi (Ed.), Panel Data Econometrics: Theoretical Contributions and Empirical Applications, Amsterdam: Elsevier Science, 3- 30.

Balkan, A. E (2016). A Cross-Sectional Analysis of Corporate Governance's Effect On Financial Performance and Profitability of The Companies In Bist Corporate Governance Index (Xkury), Phd Thesis, Yeditepe University Graduate Institute of Social Science.

Baltagi, B. H, Feng, Q. and C. Kao (2012). A Lagrange Multiplier test for Cross-sectional Dependence in a Fixed Effects Panel Data Model. Journal of the Econometrics, 170(1): 164-177.

Bebchuk, L., Cohen, A., Ferrell, A. (2005). What matters in corporate governance? Working Paper, Harvard Law School.

Boyacıŏlu, N. (2016). Firma Değeri Ve Firma Performanslari Üzerinde Kurumsal Yönetimin Rolü: Bist Kurumsal Yönetim Endeksine Kayitli Firmalar Üzerinde Bir Uygulama, Doktora Tezi, Mehmet Akif Ersoy Üniversitesi Sosyal Bilimler Enstitüsü.

Breusch, T.S and Pagan, A.R. (1980). The Lagrange Multiplier Test and Its Applications to Model Specification Tests in Econometrics. Review of Economic Studies, 47(1): 23953.

Brown, L.D., Caylor, M.L. (2006). Corporate Governance and Firm Valuation, Journal of Accounting and Public Policy, 25, 409-434.

Cengiz, H. (2016). Corporate Governance and Firm Profitability: Evidence from Turkey, International Journal of Trade, Economics and Finance, 7(6), 238-241.

Ciftci, İ., Tatoglu, E., Wood, G., Demirbag, M., Zaim, S. (2019). Corporate Governance and Firm Performance in Emerging Markets: Evidence from Turkey, International Business Review, 28, 90-103.

Dumitrescu, E.I. and Hurlin, C. (2012). Testing for Granger Non-Causality in Heterogeneous Panels. Economic Modelling, 29(4): 1450-1460.

Eberhardt, M. and Bond, S. (2009). Cross-section Dependence in Nonstationary Panel Models: A Novel Estimator. MPRA Paper, No. 17870. 
Glinkowska, B., Kaczmarek, B., (2015). Classical and modern concepts of corporate governance (Stewardship Theory and Agency Theory), Econpapers Management, 19(2), 84-92.

Gompers, P.A., Ishii, J.L., Metrick, A. (2003). Corporate Governance and Equity Prices, The Quarterly Journal of Economics, 118(1), 107-156.

Kara, E., Erdur, D.A., Karabiyık, L. (2015). Effects of Corporate Governance Level on The Financal Performance of Companies: A research on BIST Corporate Governance Index(XKURY), Ege Academic Review, Ege University Faculty of Economics and Administrative Sciences, 15(2), 265-274.

McCahery, J., Vermeulen, E. (2014). Six Components of Corporate Governance That Cannot be Ignored, Tilburg University, Tilburg Law School Legal Studies Research Paper Series, No.08/2014

OECD (2015), G20/OECD Principles of Corporate Governance, OECD Publishing, Paris.

Pesaran, M.H. (2004). General Diagnostic Tests for Cross Section Dependence in Panels, Cambridge Working Papers in Economics, 435.

Pesaran, Hashem M. (2007) "A Simple Panel Unit Root Test in the Presence of Cross Section Dependence”, Journal of Applied Econometrics, Vol.22, No.2, 265-312.

Prommin, P., Jumreornvong, S., Jiraporn P. (2014). The Effect of Corporate Governance on Stock Liquidity: The case of Thailand, International Review of Economics\&Finance, 32,132-142.

Rostami, S., Rostami, Z., Kohansal, S., The Effect of Corporate Governance Components on Return on Assets and Stock Return of Companies Listed in Tehran Stock Exchange, Procedia Economics and Finance, 36, 137 - 146.

Türk Sanayicileri ve İş Adamları Derneği (TÜSİAD), Kurumsal Yönetim En Iyi Uygulamada Kodu: Yönetim Kurulunun Yapısı ve Işsleyisi, Lebib Yalkın Yayınları, Aralık 2002.

Wan, F.W.Y., Alhaji, I.A. (2012). Corporate Governance and Firm Performance of Listed Companies in Malaysia, Trends and Development in Management Studies, 1(1), 43 65.

Westerlund, J. (2007). Estimating Cointegrated Panels with Common Factors and the Forward Rate Unbiasedness Hypothesis. Journal of Financial Econometrics, 5(3): 491-522.

Yeğen, S. (2016). Kurumsal Yönetim İlkelerine Uyum Derecesi İle Firma Performans1 Arasındaki İlişkinin İncelenmesi, Doktora Tezi, Hacettepe Üniversitesi Sosyal Bilimler Enstitüsü. 


\section{APPENDIX}

Appendix 1. Firms Listed In Corporate Governance Index as of 2019

\begin{tabular}{|c|c|}
\hline $\begin{array}{c}\text { EQUITY } \\
\text { CODE }\end{array}$ & SECTOR \\
\hline AEFES & Manufacturing Industry / Food, Beverage And Tobacco \\
\hline AGHOL & Financial Institutions / Holding And Investment Companies \\
\hline AKMGY & Financial Institutions / Real Estate Investment Trusts \\
\hline AKSA & Manufacturing Industry / Chemicals, Petroleum Rubber And Plastic Products \\
\hline AKSGY & Financial Institutions / Real Estate Investment Trusts \\
\hline ALBRK & Financial Institutions / Banks And Special Finance Corporations \\
\hline ANSGR & Financial Institutions / Insurance Companies \\
\hline ARCLK & Manufacturing Industry / Fabricated Metal Products, Machinery And Equipment \\
\hline ASELS & Technology / Defense \\
\hline AYGAZ & Manufacturing Industry / Chemicals, Petroleum Rubber And Plastic Products \\
\hline$\overline{\mathrm{CCOLA}}$ & Manufacturing Industry / Food, Beverage And Tobacco \\
\hline CRDFA & Financial Institutions / Financial Leasing And Factoring Companies \\
\hline DGGYO & Financial Institutions / Real Estate Investment Trusts \\
\hline DOAS & Wholesale And Retail Trade, Hotels And Restaurants / Wholesale Trade \\
\hline DOHOL & Financial Institutions / Holding And Investment Companies \\
\hline ENKAI & Construction And Public Works / Construction And Public Works \\
\hline EREGL & Manufacturing Industry / Basic Metal Industries \\
\hline $\begin{array}{c}\text { EQUITY } \\
\text { CODE }\end{array}$ & SECTOR \\
\hline GARFA & Financial Institutions / Financial Leasing And Factoring Companies \\
\hline GLYHO & Financial Institutions / Holding And Investment Companies \\
\hline GRNYO & Financial Institutions / Investment Trusts \\
\hline HALKB & Financial Institutions / Banks And Special Finance Corporations \\
\hline HLGYO & Financial Institutions / Real Estate Investment Trusts \\
\hline HURGZ & Manufacturing Industry / Paper And Paper Products, Printing And Publishing \\
\hline IHEVA & Manufacturing Industry / Fabricated Metal Products, Machinery And Equipment \\
\hline IHLAS & Financial Institutions / Holding And Investment Companies \\
\hline LOGO & Technology / Information Technology \\
\hline MGROS & Wholesale And Retail Trade, Hotels And Restaurants / Consumer Trade \\
\hline OTKAR & Manufacturing Industry / Fabricated Metal Products, Machinery And Equipment \\
\hline PETUN & Manufacturing Industry / Food, Beverage And Tobacco \\
\hline PGSUS & Transportation, Telecommunication And Storage / Transportation \\
\hline PINSU & Manufacturing Industry / Food, Beverage And Tobacco \\
\hline PNSUT & Manufacturing Industry / Food, Beverage And Tobacco \\
\hline PRKAB & Manufacturing Industry / Fabricated Metal Products, Machinery And Equipment \\
\hline PRKME & Mining / Coal Mining \\
\hline SISE & Financial Institutions / Holding And Investment Companies \\
\hline SKBNK & Financial Institutions / Banks And Special Finance Corporations \\
\hline TATGD & Manufacturing Industry / Food, Beverage And Tobacco \\
\hline TAVHL & Financial Institutions / Holding And Investment Companies \\
\hline TOASO & Manufacturing Industry / Fabricated Metal Products, Machinery And Equipment \\
\hline TRCAS & Financial Institutions / Holding And Investment Companies \\
\hline TSKB & Financial Institutions / Banks And Special Finance Corporations \\
\hline TTKOM & Transportation, Telecommunication And Storage / Telecommunication \\
\hline TTRAK & Manufacturing Industry / Fabricated Metal Products, Machinery And Equipment \\
\hline TUPRS & Manufacturing Industry / Chemicals, Petroleum Rubber And Plastic Products \\
\hline VESTL & Manufacturing Industry / Fabricated Metal Products, Machinery And Equipment \\
\hline YKBNK & Financial Institutions / Banks And Special Finance Corporations \\
\hline
\end{tabular}


Appendix 2. Firms Listed In Corporate Governance Index as of 2019

\begin{tabular}{|l|c|c|c|c|c|c|c|}
\hline Equity Code / Ratings & $\mathbf{2 0 1 2}$ & $\mathbf{2 0 1 3}$ & $\mathbf{2 0 1 4}$ & $\mathbf{2 0 1 5}$ & $\mathbf{2 0 1 6}$ & $\mathbf{2 0 1 7}$ & $\mathbf{2 0 1 8}$ \\
\hline AEFES & 89,39 & 93,3 & 91,255 & 95,46 & 95,77 & 95,77 & 95,83 \\
\hline AGHOL & 87,75 & 90,73 & 88,16 & 91,69 & 91,88 & 92,01 & 95,28 \\
\hline ALBRK & 82,2 & 86,16 & 83,915 & 85,86 & 87,54 & 88,05 & 89,23 \\
\hline ARCLK & 91,07 & 92,8 & 90,995 & 94,8 & 95,23 & 95,23 & 95,35 \\
\hline ASELS & 87,73 & 90,71 & 88,34 & 91,33 & 91,51 & 92,04 & 92,04 \\
\hline AYGAZ & 89,57 & 92,71 & 91,345 & 93,58 & 93,61 & 93,64 & 93,99 \\
\hline CCOLA & 88,81 & 92,01 & 90,165 & 94,02 & 94,48 & 94,52 & 94,52 \\
\hline DOAS & 82,15 & 90,05 & 91,45 & 94,2 & 95,1 & 96,3 & 96,41 \\
\hline DOHOL & 90,31 & 91,81 & 89,995 & 93,56 & 93,98 & 94,06 & 94,18 \\
\hline ENKAI & 91,59 & 91,97 & 88,735 & 91,64 & 91,75 & 91,79 & 91,8 \\
\hline GLYHO & 88,04 & 88,6 & 88,6 & 87,92 & 89,9 & 90,52 & 90,6 \\
\hline HURGZ & 90,9 & 90,9 & 90,825 & 93,58 & 92,79 & 91,27 & 92,67 \\
\hline IHEVA & 76,75 & 80,49 & 77,93 & 80,6 & 80,82 & 81,99 & 83,75 \\
\hline IHLAS & 80,94 & 81,48 & 78,565 & 80,38 & 80,46 & 81,45 & 83,32 \\
\hline LOGO & 85,97 & 89,12 & 85,47 & 90,76 & 91,24 & 90,83 & 91,14 \\
\hline OTKAR & 86,8 & 91,03 & 89,215 & 92,81 & 93,19 & 93,32 & 91,03 \\
\hline PETUN & 87,73 & 91,59 & 88,77 & 92 & 92,64 & 92,88 & 93,09 \\
\hline PNSUT & 88,67 & 91,49 & 88,625 & 91,78 & 92,37 & 92,62 & 92,71 \\
\hline PRKAB & 84,39 & 86,55 & 86,59 & 90,9 & 90,92 & 91,13 & 91,76 \\
\hline PRKME & 88,24 & 89,8 & 86,96 & 90,29 & 90,79 & 90,79 & 90,01 \\
\hline TAVHL & 92,44 & 93,97 & 92,955 & 95,19 & 95,38 & 96,17 & 96,25 \\
\hline TOASO & 90,25 & 91,39 & 87,93 & 90,61 & 91,38 & 91,48 & 92,04 \\
\hline TRCAS & 84 & 87,51 & 90,9 & 92,7 & 93,5 & 94,86 & 95,7 \\
\hline TTKOM & 88,01 & 88,02 & 85,2 & 89,08 & 90,24 & 91,75 & 92,87 \\
\hline TTRAK & 89,02 & 91,04 & 88,86 & 90,85 & 91,49 & 92,13 & 92,16 \\
\hline TUPRS & 91 & 93,43 & 89,91 & 94,41 & 94,15 & 94,67 & 94,81 \\
\hline VESTL & 88,32 & 90,94 & 89,92 & 91,24 & 93,6 & 94,86 & 96,5 \\
\hline
\end{tabular}

Appendix 3. Basic Descriptive Statistics of the Sample

\begin{tabular}{|c|c|c|c|}
\hline & \multicolumn{2}{|c|}{ Operating Profit } & Rating \\
\hline Mean & \multicolumn{2}{|c|}{760.65} & 90.54 \\
\hline Median & \multicolumn{2}{|c|}{263.92} & 91.1 \\
\hline Maximum & \multicolumn{2}{|c|}{7916.939} & 96.5 \\
\hline Minimum & \multicolumn{2}{|c|}{-106.53} & 76.75 \\
\hline Std. Dev. & \multicolumn{2}{|c|}{1231.69} & 3.99 \\
\hline Skewness & \multicolumn{2}{|c|}{2.49} & -1.17 \\
\hline Kurtosis & \multicolumn{2}{|c|}{10.39} & 4.27 \\
\hline Jarque-Bera & \multicolumn{2}{|c|}{624.77} & 55.51 \\
\hline Probability & \multicolumn{2}{|c|}{0.00} & 0.00 \\
\hline Sum & \multicolumn{2}{|c|}{143762.8} & 17112.18 \\
\hline Sum Sq. Dev. & \multicolumn{2}{|c|}{$2.85 \mathrm{E}+08$} & 2996.241 \\
\hline Observations & \multicolumn{2}{|c|}{189} & 189 \\
\hline \multicolumn{4}{|c|}{ Correlation Matrix } \\
\hline & Operating Profit & \multicolumn{2}{|l|}{ Rating } \\
\hline Operating Profit & 1 & \multicolumn{2}{|l|}{0.31} \\
\hline Rating & 0.31 & \multicolumn{2}{|l|}{0.31} \\
\hline
\end{tabular}

